| Supervisi Akademik Kinerja Guru

\title{
SUPERVISI AKADEMIK SEBAGAI SARANA PENINGKATAN KINERJA GURU SOSIOLOGI DALAM KEGIATAN BELAJAR MENGAJAR (KBM)
}

\author{
Kristina Syahreza ${ }^{1}$
}

\begin{abstract}
Abstrak
Kualitas kegiatan belajar mengajar antara lain dipengaruhi oleh guru, kualitas ini tidak lepas dari pemantauan para supervisor. Oleh karena itu untuk meningkatkan kemampuan guru dalam melaksanakan KBM maka perlu perlu mendapat perhatian dari supervisor melalui supervisi akademik yang dilakukan secara berkala. Penelitian ini bertujuan untuk mengetahui bahwa peningkatan kinerja guru sosiologi, kendala-kendala yang dihadapi pada pelaksanaan supervisi serta upaya yang dilakukan akan kendala supervisi akademik yang dihadapi diseluruh SMA Negeri kota Bengkulu.

Penelitian ini merupakan penelitian kualitatif deskriptif. Subyek penelitian adalah guru sosiologi di SMA Negeri 1 Bengkulu, SMA Negeri 2 Bengkulu, dan SMA Negeri 4 Bengkulu.Cara pengambilan data dalam penelitian ini melalui observasi langsung selama proses pembelajaran, wawancara mendalam dengan menggunakan pedoman wawancara selama wawancara berlangsung serta pencatatan dokumen yang mendukung penelitian. Teknik pengambilan sampel dengan cara proposive sampling yaitu bahwa sampling tidak mewakili populasi tetapi informasinya. Sedangkan uji validitas data menggunakan tringulasi, yaitu tringulasi sumber, tringulasi metode dan tringulasi teori. Teknis analisis data yang digunakan adalah analisis interaktif dari Milles dan Hubberman yaitu redukusi data, sajian data, dan vertifikasi/penarikan kesimpulan.

Berdasarkan penelitian ini diperoleh bahwa supervisi akademik memiliki pengaruh terhadap peningkatan kinerja guru sosiologi. Ini dapat dilihat dari penyusunan program pengajaran yaitu terlihat pada penggunaan metode yang bervarian pada proses pembelajaran, evaluasi belajar dan analisis evaluasi belajar serta penyusunan program perbaikan yaitu dengan tersedianya buku penilaian untuk melihat kemajuan belajarnya, sehingga hal ini menjadi perbaikan bagi guru sosiologi untuk memperbaiki kinerjanya kedepan. Kendala-kendala yang dihadapi pada pelaksanaan supervisi akademik yaitu kurangnya supervisi yang dilakukan oleh pengawas Diknas, keterbatasan waktu kepala sekolah untuk mensupervisi guru sosiologi, kurangnya guru senior/sejawat untuk membantu kepala sekolah pada pelaksanaan supervisi akademik serta kurangnya dana dalam RAPBS untuk pelaksanaan supervisi akademik. Upaya yang dilakukan untuk mengatasi kendala pada supervisi
\end{abstract}

\footnotetext{
${ }^{1}$ Penulis adalah alumni Program Studi Pendidikan Sosiologi, FISE, Universitas Negeri Yogyakarta
} 
akademik yaitu diskusi antar kepala sekolah/guru senior dengan guru sosiologi yang bersangkutan serta kerjasama sekolah dengan pengawas Diknas.

Kata Kunci: Akademik, Supervisi, Kinerja

\section{A. Pendahuluan}

Kualitas belajar mengajar antara lain dipengaruhi oleh kualitas kinerja guru. Kualitas guru juga tidak terlepas dari upaya pemantauan para kepala sekolah selaku supervisor dan pengawas pada tingkat kantor Departemen Pendidikan Nasional pada lingkungan wilayah kerja yang menjadi tanggung jawabnya PP No. 19/ 2005, mengamanahkan pengawas satuan pendidikan meliputi pemantauan, supervisi, evaluasi, pelaporan dan tindak lanjut. Supervisi meliputi manajerial dan akademik yang dilakukan secara teratur dan berkesinambungan oleh pengawas dari kepala satuan pendidikan. Oleh karena itu, untuk meningkatkan kemampuan guru dalam melaksanakan proses belajar mengajar perlu secara terus menerus mendapat perhatian dari pengawas pendidikan. Peningkatan ini akan lebih berhasil apabila dilakukan oleh guru dengan kemampuan dan usaha sendiri.

Selain berperan sebagai pendidik dan pengajar, guru dituntut untuk dapat meningkatkan kualitas dan mengelola proses belajar mengajar di kelas, hal ini sangat tergantung oleh kualitas guru. Ini bisa dipahami karena guru merupakan suatu profesi, yang artinya suatu jabatan atau pekerjaan yang memerlukan keahlian khusus. Ukuran kinerja guru dilihat dari tanggung jawab menjalankan amanah profesi yang diembannya. Semua itu akan terlihat pada kepatuhan dan loyalitas di dalam menjalankan tugasnya di dalam kelas. Oleh karena itu usaha meningkatkan kemampuan guru dalam melaksanakan proses belajar mengajar, perlu secara terus menerus mendapat perhatian dari penanggung jawab pendidikan. Peningkatan ini akan berhasil apabila dilakukan oleh guru dengan kemauan dan usaha mereka sendiri sebagai komitmen terhadap tugas mereka. Namun seringkali guru masih memerlukan bantuan dari orang lain, dalam hal ini pengawas sekolah.

Dalam UU No. 2 tahun 1989 tentang Sistem Pendidikan Nasional dan Permen No. 29 tahun 1990 tentang Pendidikan Menengah ditegaskan bahwa pada jenjang pendidikan menengah, selain pengawasan, kepala sekolah juga mendapat tugas sebagai supervisor yang diharapkan dapat setiap kali berkunjung ke kelas dan mengamati kegiatan guru yang sedang mengajar (Suharsimi Arikunto, 2004: 3). Namun sejauh ini koordinasi antara pengawas dan kepala sekolah dalam melakukan pembinaan terhadap guru belum terjadi secara efektif. Dalam Kenyataannya, baik pengawas maupun kepala sekolah, belum dapat melaksanakan supervisi dengan baik, bahkan semakin 
berkurang keefektifannya sehingga supervisi kurang mendapat sentuhan pengawas. Kalaupun ada, tidak dilaksanakan semestinya, sehingga guru beranggapan bahwa supervisi yang dilaksanakan oleh pengawas atau kepala sekolah tidak dapat membantu mereka dalam memecahkan permasalahan yang mereka hadapi ketika melaksanakan tugas, melainkan mencari kelemahan dan kesalahan, bukan mencari jalan keluar dari permasalahan tersebut. Sedangkan tujuan supervisi itu sendiri untuk membantu guru dalam memperbaiki proses belajar mengajar melalui peningkatan kompetensi guru itu sendiri dalam melaksanakan tugas profesional mengajarnya.

Dari beberapa permasalahan diatas maka supervisor perlu mengambil langkah untuk supervisi akademik yaitu meliputi tahap perencanaan, pelaksanaan, hasil penilaian dan tahap pelaporan. Dari hasil tersebut maka supervisor mengkonfirmasikan kepada kepala sekolah untuk melakukan pembinaan lebih lanjut terhadap guru terutama guru sosiologi. Namun dari langkah yang diambil supervisor tersebut mengalami kendala yaitu kurangnya kesiapan guru yang akan di supervisi, jadwal pelajaran guru pada pelaksanaan supervisi bersilangan serta pemberian pembinaan dari hasil supervisi belum ditindak lanjuti oleh guru dan kepala sekolah. Usaha ini akan berhasil apabila ada kerjasama dan sikap kooperatif baik guru sendiri maupun pengawas sekolah/kepala sekolah yang menjalankan tugasnya sebagai supervisor.

Berdasarkan permasalahan yang ada, maka tujuan penelitian ini untuk mengetahui: 1) untuk mengetahui bagaimana pelaksanaan supervisi akademik di SMA Negeri Bengkulu, 2) untuk mengetahui peningkatan kinerja guru sosiologi di SMA Negeri Bengkulu, setelah dilakukannya supervisi akademik, 3) untuk mengetahui hambatan yang ada dalam supervisi akademik di SMA Negeri Bengkulu, dan 4) untuk mengetahui bagaimana solusi jika terjadinya hambatan dalam supervisi akademik di SMA Negeri Bengkulu.

\section{B. Kajian Pustaka}

1. Tinjauan Supervisi Akademik

Supervisi adalah bantuan professional guru kepada guru, melalui siklus perencanaan yang sistematis, pengamatan yang cermat, dan umpan balik yang obyektif dan segera. Dengan cara itu guru dapat menggunakan balikan tersebut untuk memperbaiki kinerjanya. Menurut Boardman, dalam Piet A. Sahertian (1981: 19) supervisi adalah suatu usaha menstimulir, mengkoordinir, dan membimbing secara berlanjut pertumbuhan guru-guru baik secara pribadi maupun kelompok agar lebih memahami dan lebih efektif dalam mewujudkan seluruh fungsi pengajaran.

Mc. Nerney, dalam Piet A. Sahertian (1981: 20) supervisi bukan 
usaha pengarahan yang membentuk pribadi guru selaras dengan pola yang dikehendaki oleh supervisor, tetapi supervisor membantu guru agar guru berkembang menjadi pribadi yang sesuai dengan kodratnya. Kimball Willes, dalam Piet A. Sahertian (1981: 21) menyatakan dalam kegiatan supervisi pendidikan bukan hanya profesi guru yang bertumbuh, tetapi juga pribadinya. Dalam pengertian lain supervisi merupakan peningkatan makna dari inspeksi yang berkonotasi mencari-cari kesalahan.

Kegiatan pokok supervisi adalah melakukan pembinaan kepada sekolah pada umumnya dan guru pada khususnya agar kualitas pembelajarannya meningkat. Sebagai dampak meningkatnya kualitas pembelajaran, tentu dapat eningkat pula prestasi belajar siswa, dan itu berarti meningkatlah kualitas lulusan sekolah itu. Menurut Suharsimi Arikunto (2004: 5) supervisi akademik adalah supervisi yang menitik beratkan pengamatan pada masalah akademik, yaitu yang langsung berada dalam lingkup kegiatan pembelajaran yang dilakukan oleh guru untuk membantu siswa ketika sedang dalam proses belajar.

Berdasarkan beberapa pengertian para ahli yang sudah dipaparkan, maka dapat diambil kesimpulan bahwa supervisi akademik adalah sebagai proses usaha dari pihak atasan untuk memperbaiki, mengarahkan dan memperkembangkan guru-guru yang berhubungan dengan pembelajaran. Disini guru adalah sebagai penentu keberhasilan siswasiswa dalam mengikuti kegiatan belajar mengajar. Untuk itu kegiatan supervisi lebih ditekankan pada peningkatan kinerja guru sosiologi.

Soekarto (1989: 266-287)

mengemukakan bahwa tujuan supervisi pendidikan di sekolah dapat dirumuskan secara rinci berikut.

a. Membantu guru agar dapat merencanakan, melaksanakan dan menilai program kegiatan suatu pelajaran

b. Membantu guru dalam menyusun desai mengajar

c. Membantu guru melaksanakan kegiatan belajar mengajar

d. Membantu guru dan menilai proses hasil belajar, mengajar

e. Membantu guru meningkatkan kegiatan belajar mengajar dikelas termasuk mengelola kelas yang berhasil

f. Membantu guru dalam meningkatkan cara-cara menilai hasil belajar siswa

g. Membantu seluruh staf sekolah dalam meningkatkan pelaksanaan bimbingan dan penyuluhan termasuk bimbingan karir:

Meningkatkan pelaksanaan bimbingan penyuluhan; (2) Meningkatkan karir

h. Membantu guru dalam menerjemahkan kurikulum ke dalam program mengajar: (1) Memahami landasan kurikulum; (2) Meningkatkan pemahaman tentang intra 
Supervisi Akademik Kinerja Guru

kulikuler, ko kulikuler, ekstrakulikuler.

Supervisi akademik dilakukan oleh pelaku yang berkompeten yaitu pengawas dan kepala sekolah. Untuk itu selaku penanggung jawab supervisi perlu terus-menerus berpikir untuk mencari variasi langkah kegiatan dengan maksud memperoleh data yang lebih baik dan model pembinaan yang lebih efektif. Adapun langkah-langkah supervisi akademik dalam penelitian ini meliputi (Dr. Manaf Sumantri dalam makalah seminar kepengawasan, 2008).

a. Tahap Perencanaan

Dalam tahap perencanaan yang dilakukan adalah menentukan waktu pelaksanaan dan perangkat supervisi.

b. Tahap Pelaksanaan

Pada tahap pelaksanaan ini meliputi pemeriksaan dokumen (kurikulum) yaitu standar kompetensi mata pelajaran, program tahunan, program semester, silabus dan sistem penilaian semester, rencana/ skenario pembelajaran untuk KD yang disajikan serta buku nilai yang telah diisi semua tagihan yang telah dilaksanakan mencakup aspek kognitif, psikomotorik, dan afektif. Tahap kedua yaitu kunjungan kelas dan mengamati /mencatat kegiatan pembelajaran yang sedang berlangsung di dalam kelas.

c. Tahap Hasil Penilaian Setelah dilakukan perencanaan dan pelaksanaan maka selanjutnya menentukan rumus penilaian dan hasil penilaian.

d. Tahap Pelaporan

Pada tahap pelaporan, pengawas dan kepala sekolah memberikan hasil pelaksanaan supervisi kepada Dinas Pendidikan tingkat kabupaten/kota. sehingga dapat direkomendasikan guru mana yang memerlukan pembinaan lebih lanjut.

\section{Tinjauan Kinerja Guru Sosiologi \\ Ada banyak pendapat mengenai batasan kinerja} (performance) diantara beberapa ahli tersebut memberi batasan berbeda yang satu dengan yang lainnya. hal ini sesuai dengan sudut pandang dari masing-masing para ahli tersebut, namun secara umum batasan yang dikemukakan masih mempunyai persamaan. Bernardin dan Russel dalam Sianipar (2000: 5) memberi batasan kinerja adalah hasil dan fungsi pekerjaan atau kegiatan tertentu selama suatu periode waktu tertentu. Sedangkan menurut Maier dalam As'ad (1999: 47) mengemukakan kinerja diberi batasan sebagai kesuksesan seseorang dalam melakukan pekerjaannya.

Berdasarkan Peraturan Pemerintah Nomor 10 tahun 1979 tentang penilaian pelaksanaan pekerjaan Pegawai Negeri Sipil dijelaskan bahwa kinerja adalah hasil kerja yang dicapai oleh seorang pegawai negeri sipil dalam melaksanakan tugas yang dibebankan kepadanya. Pendapat 
lain dikemukakan oleh Simamora (1997: 23) Kinerja pegawai (employee performance) adalah tingkatan dimana para pegawai mampu mencapai persyaratan-persyaratan pekerjaan. Penilaian kerja adalah proses yang mengukur kinerja pegawai. penilaian kerja pada umumnya mencakup baik aspek kualitatif maupun kuantitatif dari pelaksanaan pekerjaan. Siagian, penilaian kerja para pegawai merupakan bagian penting dari seluruh proses kekaryaan pegawai yang bersangkutan. Pentingnya penilaian kerja yang rasional dan diterapkan secara obyektif terlihat pada paling sedikit dua kepentingan, yaitu kepentingan pegawai yang bersangkutan sendiri dan kepentingan organisasi. Bagi organisasi system penilaian kinerja yang baik bermanfaat untuk kepentingan: (1) Mendorong peningkatan kinerja, (2) Sebagai bahan pengambilan keputusan dalam pemberian imbalan, (3) untuk kepentingan mutasi pegawai, (4) Guna menyusun program pendidikan dan pelatihan, (5) Membantu para pegawai menentukan rencana karirnya.

$$
\text { Gomes dalam Johan }
$$

Martono (2005: 22) mengemukakan bahwa dilihat dari titik acuan penilaian, terdapat tiga tipe penilaian kerja yakni.

a. Penilaian kinerja berbagai hasil (result-based performance appraisal evaluation). Tipe kriteria kinerja ini berdasarkan pencapaian tujuan organisasi, atau mengukur hasil-hasil akhir. b. Penilaian kinerja berdasarkan prilaku (behavior-based performance appraisal /evaluation). Tipe kinerja ini mengukur sarana, pencapaian sasaran, dan bukan hasil akhir.

c. Penilaian kerja berdasarkan Judgment (judgment-based performance appraisal/ evaluation). Ini merupakan tipe kriteria kinerja yang menilai dan mengevaluasi kinerja berdasarkan deskripsi perilaku yang spesifik yakni.

1) Quantity of work yaitu jumlah kerja yang dilakukan dalam satu periode yang ditentukan.

2) Quality of work yaitu kualitas kerja yang dicapai berdasarkan syarat-syarat kesesuaian dan kesiapannya

3) Job knowledge yaitu luasnya pengetahuan mengenai pekerjaan dan ketrampilannya.

4) Creativiness yaitu keaslian gagasan yang dimunculkan dan tindakan-tindakan untuk menyelesaikan persoalanpersoalan yang timbul.

5) Cooperation yakni kesediaan untuk bekerjasama dengan orang lain (sesama anggota organisasi)

6) Dependability yakni kesadaran dan dapat dipercaya dalam hal kehadiran dan penyelesaia kinerja.

7) Initiative yakni semangat untuk melaksanakan tugastugas baru dan dalam memperbesar tanggung jawabnya. 
Supervisi Akademik Kinerja Guru

8) Personal Qualities yakni menyangkut kepribadian, kepemimpinan, keramahtamahan dan integrasi pribadi.

Terdapat beberapa kegiatan yang harus dilakukan guru dalam proses pembelajaran, yakni: (1) Menyusun program pengajaran, termasuk merumuskan tujuan, (2) Menentukan materi pelajaran yang sesuai dengan tujuan tersebut, (3) Menentukan alat peraga/media pembelajaran yang dapat digunakan untuk memperjelas dan mempermudah penerimaan materi pembelajaran oleh siswa serta dapat menunjang tercapainya tujuan tersebut, (4) Memilih dan menggunakan metode belajar yang tepat, (5) Menentukan alat evaluasi yang dapat mengukur tercapai tidaknya tujuan yang hasilnya dapat dijadikan sebagai feedback bagi guru dalam meningkatkan kualitas mengajarnya maupun kuantitas belajar siswa (Uzer Usman, 2001:18).

Berdasarkan dari uraian diatas maka kinerja guru sosiologi dijelaskan dalam Permen No. 16 tahun 2007 tentang standar kualifikasi akademik dan kompetensi guru. Maka kompetensi guru mata pelajaran sosiologi pada SMA/MA/SMK/MAK yaitu: (1) memahami materi dan pola pikir keilmuan mata pelajaran sosiologi; (2) memahami langkah-langkah kerja ilmu-ilmu sosial; menunjukkan manfaat pelajaran sosiologi. Dari kompetensi tersebut maka direalisasikan melalui tugas pokok guru yang diatur dalam Kep. Menpan No. 84/1993 (pasal 3).

\section{Kegiatan Sosiologi}

Pembelajaran

Pembelajaran merupakan proses membuat orang belajar. Tujuannya ialah membantu orang belajar atau merekayasa lingkungan sehingga memberi kemudahan bagi orang yang belajar. Istilah pembelajaran berasal dari kata instructional, menunjuk pada dua kegiatan yaitu belajar dan mengajar. Istilah lain yang sering dipakai adalah proses belajar mengajar. Nana Sudjana (1990:1) mendefinisikan pembelajaran sebagai "proses yang mengandung serangkaian perbuatan guru dan siswa atas dasar timbal balik yang berlangsung dalam situasi edukatif untuk mencapai tujuan tertentu".

Berdasarkan standar kompetensi guru (Depdiknas, 2004: 92), maka kegiatan pembelajaran sosiologi terdapat pada indikator kompetensinya, Adapun kompetensi dan indikator bidang studi sosiologi berikut ini.

a. Mengembangkan pemahaman siswa tentang sosiologi dan antropologi sebagai ilmu dan metode serta melatih siswa untuk menggunakannya dalam memahami fenomena sosial budaya.

b. Mengembangkan pemahaman siswa tentang masyarakat sebagai sistem sosial/ budaya dan melatih siswa dalam menentukan 
sikap/perilaku sebagai bagian dari sistem tersebut.

c. Mengembangkan pemahaman siswa tentang nilai dan norma sebagai alat untuk menciptakan keteraturan di masyarakat dan melatih siswa agar konsisten dalam bersikap dan berprilaku sesuai dengan nilai dan norma yang berlaku.

d. Mengembangkan pemahaman siswa tentang keteraturan sosial sebagai salah satu syarat mencapai keseimbangan sosial dan melatih siswa untuk berperilaku yang mendorong terciptanya keteraturan sosial.

e. Mengembangkan pemahaman siswa tentang struktur sosial berdasarkan parameter dan melatih siswa untuk menentukan sikap dalam menghadapi berbagai perbedaan dalam masayarakat.

f. Mengembangkan keterampilan siswa dalam melakukan studi etnografis dalam rangka memahami dan menghargai keanekaragaman budaya masyarakat Indonesia.

g. Mengembangkan pemahaman siswa tentang konsep mobilitas sosial.

h. Mengembangkan pemahaman siswa tentang lembaga atau pranata sosial yang ada di masyarakat dan melatih siswa dalam menganalisis persoalan yang terjadi sehubungan inkonsistensi fungsi pranata sosial.

i. Mengembangkan pemahaman siswa dan cara menyikapi proses perubahan sosial/budaya serta dampaknya.

j. Mengembangkan pemahaman siswa tentang modernisasi dan cara menyikapinya.

k. Mengembangkan keterampilan siswa dalam melakukan investigasi masalah-masalah sosial budaya berdasarkan metode penelitian sosial.

\section{Pembahasan}

1. Pelaksanaan Supervisi

Akademik Di SMA Negeri 1 Bengkulu, SMA Negeri 2 Bengkulu dan SMA Negeri 4 Bengkulu.

Supervisi bertujuan untuk membantu guru dalam mempebaiki kinerjanya sebagai pengajar. Dari data penelitian yang penulis dapatkan bahwa supervisi akademik disetiap SMA Negeri yang peneliti ambil telah terlaksana dengan cukup baik. Namun untuk pelaksanaan supervisi yang peneliti lihat, sejauh ini masih banyak kendala, terutama kendala pada supervisor yang akan mensupervisi dan Keterbatasan dana. Untuk penjelasan pelaksanaan supervisi akademik di setiap SMA Negeri yang peneliti teliti, maka dapat diuraikan di bawah ini:

a. Pelaksanaan Supervisi Di SMA Negeri 1 Bengkulu 
Berdasarkan pengamatan dan hasil wawancara yang dilakukan oleh peneliti pada pelaksanaan supervisi yaitu bahwa pelaksanaan supervisi di SMA Negeri 1 Bengkulu hanya dilaksanakan sekali dalam 1 semester oleh pengawas dari Diknas, berarti dalam 1 tahun ajaran itu, supervisi untuk guru sosiologi hanya dilakukan 2 kali dalam 1 tahun pelajaran (R1, Wawancara Bapak Fazrul Hamidi, 1 Mei 2009). Menurut pak Fazrul Hamidy selaku Kepala sekolah SMA Negeri 1 Bengkulu, bahwa supervisi yang dilaksanakan masih banyak dilakukan oleh pihak sekolah terutama dilakukan oleh kepala sekolah sendiri dengan bantuan guru senior atau istilahnya guru sejawat.

$$
\text { Pelaksanaan supervisi }
$$

akademik ini tidak terlebih dahulu bermusyawarah dengan guru sosiologi untuk penetapan jadwal pelaksanaannya, karena menurut Kepala Sekolah bahwa setiap guru sudah siap untuk disupervisi kapanpun sehingga tidak ada guru yang tidak siap untuk disupervisi (R1, Wawancara Bapak Fazrul Hamidi, 1 Mei 2009). Pelaksanaan ini biasanya dilaksanakan mulai dari tahap perencanaan hingga tahap pelaporan, biasanya yang dinilai dari supervisi ini lebih banyak pada persiapan mengajar guru, perangkat pengajaran dan penguasaan guru terhadap materi yang akan disampiakan. Pada pelaksanaan supervisi ini peran pengawas Diknas sangat kurang sehingga tugas ini lebih banyak dilaksanakan oleh Kepala sekolah dengan bantuan guru senior (R1, Wawancara Bapak Fazrul Hamidi, 1 Mei 2009). Terkadang hal ini membebani kepala sekolah, sehingga kepala sekolah lebih banyak berharap kepada guru senior untuk mensupervisi guru sosiologi, sedangkan jumlah guru senior yang ada hanya sedikit, ini dikarenakan banyak dari mereka sudah pensiun atau habis masa jabatannya.

b. Pelaksanaan Supervisi Akademik Di SMA Negeri 2 Bengkulu

Dari hasil penelitian yang dilakukan di SMA Negeri 2 Bengkulu ini, pelaksanaan supervisinya dilaksanakan 2 kali dalam 1 tahun pelajaran yaitu pada semester 1 dan semester 2 , ini untuk pelaksanaan supervisi yang dilakukan oleh pengawas dari Diknas dan kepala sekolah (R3, Wawancara Bapak Yandiono, 30 April 2009). Selain itu pelaksanaan supervisi juga dilakukan oleh kepala sekolah dibantu oleh wakil kurikulum dan guru-guru senior. Disini wakil kurikulum dilibatkan untuk persiapan-persiapan seperti penentuan waktu atau jadwal supervisi dan bahan-bahan lainnya. Sehingga pelaksanaan supervisi ini berjalan dengan efektif sekolah (R3, Wawancara Bapak Yandiono, 30 April 2009). Pada pelaksanaan supervisi ini menurut pak Yandiono saat diwawancarai bahwa sebelum melaksanakan supervisi terlebih dahulu bermusyawarah kepada 
guru-guru sosiologi yang akan disupervisi.

Hubungan kerjasama antara kepala sekolah dengan pengawas dari Diknas pada saat pelaksanaan supervisi sangat baik, hal ini dikarenakan bagi pihak sekolah bahwa dengan adanya pengawas dari Diknas ini, banyak membantu pihak sekolah sendiri. Dan juga dengan adanya pengawas dari Diknas ini banyak guru yang terpacu untuk lebih menonjolkan diri. Selain itu tentunya mereka lebih fokus saat melaksanakan supervisi dibandingkan kepala sekolah yang akan mensupervisi. Biasanya bila hasil supervisi itu baik maka guru tersebut akan diberi reward yaitu biasanya berupa penghargaan, serta hasil tersebut akan dipertahankan. Sedangkan bila hasil penilaian supervisi guru sosiologi tidak baik maka akan dilakukan pembinaan terhadap guru tersebut sekolah (R3, Wawancara Bapak Yandiono, 30 April 2009).

c. Pelaksanaan Supervisi Akademik Di SMA Negeri 4 Bengkulu

Dari data yang peneliti dapatkan dari penelitian di SMA Negeri 4 Bengkulu ini, pelaksanaan supervisi akademik yang dilakukan pengawas dari Diknas hampir sama dengan SMA Negeri 1 dan 2 Bengkulu, yaitu satu tahun 2 kali dilaksanakan supervisi yakni pada semester awal dan semester akhir itu untuk yang resmi. Sedangka untuk yang tidak resminya dilakukan oleh pihak sekolah, dan supervisi ini dilaksanakan secara terus-menerus. Pada pelaksanaan supervisi ini selain melibatkan kepala sekolah dan pengawas guru senior atau guru sejawat juga diikut sertakan (R5, Wawancara Ibu Nismah, 29 April 2009).

Pelaksanaan supervisi biasanya dilakukan dengan diskusi antar guru sosiologi tersebut, hal ini dilakukan karena kesibukkan kepala sekolah yang memiliki tugas lain selain mensupervisi guru. Pada pelaksanaan supervisi ini aspek yang diamati atau yang dinilai yaitu persiapan perangkat pembelajaran, kemampun guru tersebut saat mengajar dan penguasaan kelas saat proses pembelajaran berlangsung, itu yang biasanya dilakukan bila pengawas Diknas yang mensupervisi (R5, Wawancara Ibu Nismah, 29 April 2009).

Hasil wawancara dengan guru sosiologi yakni ibu Sri mengemukakan bahwa pelaksanaan supervisi setiap 3 bulan sekali itu, belum dilaksanakan, yang jelas programnya ada hanya dalam 1 semester, itu memang ada pengawas yang masuk (R6, Wawancara Ibu Sri, 29 April 2009). Dari penuturan responden ini, maka supervisi yang dilakukan oleh pengawas dari Diknas ini masih kurang, apalagi supervisi itu seharusnya dilaksanakan 3 kali dalam 1 semester, sehingga kinerja guru sosiologi dapat dikontrol sekaligus dapat ditingkatkan lagi dibandingkan semester 1 kali (R6, Wawancara Ibu Sri, 29 April 2009).

Jadi kesimpulan dari semua hasil penelitian yang di dapatkan dari lapangan bahwa pada pelaksanaan supervisi akademik 
sudah cukup baik, ini dibuktikan dengan diadakannya supervisi oleh pengawas dari Diknas, yang dilakukan dua kali dalam satu tahun ajaran. Di samping itu selain supervisi yang dilaksanakan oleh pengawas Diknas, pihak sekolah juga melakukan supervisi akademik yaitu kepala sekolah bersama guruguru senior sosiologi yang ikut membantu. Namun kendala yang di dapatkan dari ketiga SMA negeri Bengkulu yang di dapatkan pada pelaksanaan supervisi akademik ini, yaitu pertama, keterbatasan waktu antara kepala sekolah dengan guru sosiologi yang akan disupervisi dan yang kedua keterbatasan dana dalam RAPBS untuk pelaksanaan supervisi akademik.

\section{Peningkatan Kinerja Guru Sosiologi Di SMA Negeri 1 Bengkulu, SMA Negeri 2 Bengkulu Dan SMA Negeri 4 Bengkulu.}

a. Peningkatan Kinerja Guru Sosiologi Di SMA Negeri 1 Bengkulu

Berdasarkan hasil wawancara bahwa di SMA Negeri 1 Bengkulu didapatkan bahwa kinerja guru sosiologinya sudah cukup baik walaupun terkadang masih bersifat situasional yakni kadang-kadang setelah dilaksanakan supervisi tersebut, kinerja guru sosiologi mengalami peningkatan tepai terkadang bisa saja kinerja guru tersebut dapat menurun (R1, Wawancara Bapak Fazrul Hamidi, 1 Mei 2009). Peningkatan kinerja guru sosiologi disini dapat dilihat dari hasil supervisi yang dilakukan oleh pengawas dari Diknas dan kepala sekolah yang rata-rata hampir mencapai nilai 100. Dan ini bisa terlihat dalam melaksanakan tugastugas kesehariannya sebagai guru (R1, Wawancara Bapak Fazrul Hamidi, 1 Mei 2009).

Kemudian bila hasil supervisi kinerja guru itu mengalami peningkatan maka guru yang bersangkutan akan mendapatkan reward, yaitu biasanya berupa penghargaan dan itu diberikan 1 tahun 2 kali (R1, Wawancara Bapak Fazrul Hamidi, 1 Mei 2009). Data lainnya yang peneliti dapatkan yaitu bahwa guru sosiologi sudah hadir 90 persen dalam KBM. Namun untuk jam wajib pembelajaran bagi guru sosiologi, itu belum mencapai 24 jam dan menurut keterangan dari kepala sekolah bahwa biasanya dalam mengajar sosiologi, itu biasanya dilakukan team teaching yaitu guru melaksanakan pembelajaran di dalam kelas bersama dengan guru sosiologi yang lain (R1, Wawancara Bapak Fazrul Hamidi, 1 Mei 2009).

Pada Kegiatan pokoknya guru masih menggunakan metode tradisonal yaitu hanya ceramah dan Tanya jawab saja. Untuk bagian media dan alat guru menggunakan gambar-gambar yang berkaitan dengan materi yang diajarnya. Tapi dari kegiatan pokok ini permasalahan yang peneliti temukan yaitu keterlibatan siswa masih pasif dan lebih banyak guru yang menyampaikan atau bertanya kepada siswa, penggunaan bahasa 
daerah yang masih kental pada saat proses pembelajaran berlangsung, dan pengelolaan waktu masih kurang karena guru sering melebihkan waktu sehingga untuk jam pelajaran lainnya menjadi berkurang (R2, Observasi Ibu Siti, 5 Mei 2009).

Sarana dan prasarana yang digunakan sudah cukup lengkap yaitu sudah adanya OHP dan ruang multimedia. Untuk buku pegangan itu masih kurang karena masih menggunakan buku pengantar sosiologi SMA saja. Di lain hal guru sosiologi juga mengikuti forum MGMP nya, menurut keterangan dari responden bahwa pelaksanaan MGMP tersebut dilaksanakan sebulan sekali, dan biasanya yang dibicarakan yaitu tentang perangkat pembelajaran dan persiapan ulangan akhir semester. Dari data yang peneliti dapatkan bahwa untuk evaluasi dan hasil evaluasi belajar siswa itu tidak mengalami permasalahan.

b. Peningkatan Kinerja Guru Sosiologi Di SMA Negeri 2 Bengkulu

Dari hasil penelitian yang didapatkan bahwa setelah dilaksanakan supervisi akademik, peningktan kinerja guru sosiologi di SMA Negeri 2 Bengkulu sudah mengalami peningkatan. Hal ini dapat dilihat dari penilaiannya yang sudah cukup baik yaitu berkisar antara 75 hingga 85 (R3, Wawancara Bapak Yandiono, 30 April 2009). Ini dikarenakan mayoritas guru-guru sosiologinya masih baru mengajar. Bagi guru yang kinerjanya bagus maka akan diberikan reward yang biasanya berupa penghargaan tetapi bagi guru yang kinerjanya tidak bagus akan diberikan bimbingan (R3, Wawancara Bapak Yandiono, 30 April 2009).

Dari hasil yang didapatkan bahwa perangkat pembelajaran guru belum lengkap yaitu program tahunan beserta silabusnya dan sistem penilaiannya yang masih belum lengkap serta buku nilainya masih berisi nilai hasil ulangan harian saja (R4, Observasi Ibu Yenni, 4 Mei 2009). Untuk evaluasi belajar siswa dari hasil penelitian sudah berjalan cukup baik ini terlihat dari adanya pemberian tugas terstruktur dan tidak terstruktur juga pada pelaksanaan remedial dan pengayaan sudah berjalan dengan baik. Selain itu penggunaan media dan alat sudah baik, yaitu pada saat pembelajaran sudah menggunakan kaset-kaset, LCD, buku pegangan mengajar dan buku referensi. Selain pembelajaran yang dilakukan di dalam kelas, menurut responden kadang-kadang pemelajaran juga dilakukan diluar kelas misalnya kunjungan ke penjara.

Untuk pelaksanaan MGMP Sosiologi sudah sangat rutin diikuti oleh responden yaitu 1 bulan sekali dan menurut keterangan dari beliau bahwa pada forum ini biasanya yang dibicarakan masih mengenai RPP dan pembuatan soal-soal ujian. Kemudian untuk pelatihan atau penataran guru sosiologi itu baru 1 orang yang mengikuti sedangkan selama 5 tahun mengajar di Sekolah ini, ia belum sama sekali 
mendapatkan pelatihan atau penataran.

c. Peningkatan Kinerja Guru Sosiologi Di SMA Negeri 4 Bengkulu

Dari data yang peneliti dapatkan bahwa kinerja guru sosiologi di SMA Negeri 4 Bengkulu ini sudah cukup baik. Temuan data yang peneliti dapatkan dari hasil penelitian yang terkait kinerja guru sosiologinya yaitu bahwa jam wajib mengajar guru sosiologi masih belum mencapai 24 jam (R5, Wawancara Ibu Nismah, 29 April 2009). Rata-rata guru sosiologi yang mengajar di SMA Negeri 4 ini masih mencapai 18 jam dan untuk menutupi kekurangan ini biasanya guru-guru tersebut diberikan tugas tabahan lainnya di luar tugas mengajar, tetapi karena responden yang peneliti teliti adalah wakil kepala sekolah sekaligus guru sosiologi kelas 3, maka jam wajib mengajarnya hanya terpenuhi 12 jam saja.

Terkait dengan Kinerja guru disini yang didapatkan dari hasil penelitian bahwa kehadiran guru sosiologi sudah baik dan hasil penilaian dari supervisi yang dilakukan oleh kepala sekolah dan pengawas sekolah beserta guru senior itu rata-rata sudah cukup baik, ini dapat dilihat dari penilaian masing-masing guru sosiologi sudah mencapai 90 lebih (R5, Wawancara Ibu Nismah, 29 April 2009). Dari supervisi yang paling menonjol pada kinerja guru sosiologi yaitu kemampuan mengajar dan penguasaan kelas.
Bila hasil dari supervisi ini mampu meningkatkan kinerja guru sosiologi, maka ada pemberian reward bagi guru-guru yang memiliki prestasi kerja yang baik, yaitu berupa penghargaan. Tapi sebaliknya bila prestasi kerja guru menurun maka akan dilakukan bimbingan dan pemberian saran.

Untuk penggunaan media dan alat bantu pembelajaran di kelas sudah cukup baik, untuk media yang biasanya digunakan yaitu CD dan powerpoint. Sedangkan untuk buku pegangan sudah baik yaitu buku pengantar untuk siswa ditambaha buku-buku dari perguruan tinggi selain dari buku pegangan, ada juga buku referesi lainnya yang dipakai yaitu majalah, Koran dan siaran televisi. Pada pelaksanaan evaluasi yang diterapkan responden sudah baik ini dapat dilihat dari buku-buku nilai yang dimiliki responden yang terdiri dari buku penilaian siswa yaitu dari catatan sikap, penilaian sikap sementara serta penilaian observasi dan diskusi siswa, itu semua sudah lengkap diluar dari nilai harian dan nilai akhir semester.

Dengan adanya metode yang bervarian dan buku penilaian tersebut, hal ini bagi responden dapat memotivasi dirinya untuk lebih meningkatkan kinerjanya kedepan. Hal lainnya yang ditemukan di SMA Negeri 4 Bengkulu ini bahwa mereka juga menyiapkan jam sore untuk mengatasi kekurangan waktu yaitu dimulai dari pukul 14.30 wib hingga 16.00 wib. Untuk penataran dan 
pelatihan responden sudah mengikuti sampai tingkat nasional. Walaupun responden sendiri bukan berlatar belakangkan dari Pendidikan Sosiologi, untuk memenuhi kebutuhan sekolah akan guru sosiologi, responden belajar sosiologi melalui penataranpenataran dan seminar yang sampai sekarang masih diikuti oleh beliau.

Dari hasil penelitian yang didapatkan dari ketiga SMA Negeri Bengkulu, yaitu bahwa kinerja guru sosiologi mengalami peningkatan. Hal ini terlihat pada penyusunan program pengajaran yang sudah cukup lengkap, penyajian program pengajaran yang sudah cukup baik, yaitu sudah sesuai dengan program pengajaran, ini dapat dilihat dari segi metode yang digunakan hampir bervarian pada pembelajarannya serta pengadaan pembelajaran diluar kelas yang sudah dilaksanakan, untuk evaluasi dan analisis pembelajaran sudah cukup baik, ini dilihat dari ketersediaannya buku penilaian siswa untuk masing aspek yaitu kognitif dan afektif.

Selain dari penjelasan diatas nilai dari hasil supervisi yang didapatkan yaitu rata-rata hampir delapan puluh sampai dengan sembilan puluh, ini juga dapat membuktikan bahwa pelaksanaan supervisi akademik dapat meningkatkan/memiliki pengaruh pada kinerja guru sosiologi, walaupun peningkatan ini sedikit, namun hal ini memiliki pengaruh yang positif terhadap kinerja guru tersebut.
3. Hambatan Supervisi

Akademik Di SMA Negeri 1

Bengkulu, SMA Negeri 2

Bengkulu, Dan SMA Negeri 4

Bengkulu

Dari penelitian yang dilakukan di 3 SMA Negeri ini, ditemukan beberapa hambatan pada supervisi akademik dan pembelajaran sosiologi berikut ini.

a. Ketidak tepatan waktu antara kepala sekolah dengan guru yang akan disupervisi, ini dikarenakan kesibukan kepala sekolah yang memiliki tugas internal dan eksternal sehingga waktu yang digunakan untuk melakukan supervisi menjadi terbatas (R1, R3, R5, Wawancara).

b. Hambatan lainnya pada pelaksanaan supervisi akademik yaitu tidak adanya dana yang disediakan dalam RAPBS untuk supervisi akademik (R1, R3, R5, Wawancara).

c. Supervisi akademik yang dilakukan pengawas masih sangat kurang yaitu hanya 2 kali dalam satu tahun ajaran, Selain kurangnya supervisi yang dilaksanakan, hambatan lainnya yaitu masih kurangnya guru senior untuk membantu sejawatnya dalam memperbaiki kinerja mengajarnya (R1, R3, R5, Wawancara).

d. Guru masih banyak takut untuk disupervisi ini dikarenakan, bahwa supervisi itu bukannya membantu mereka melainkan berupaya untuk mencari-cari 
Supervisi Akademik Kinerja Guru

kelemahan mereka dalam mengajar (R1, Wawancara Bapak Fazrul Hamidi, 1 Mei 2009).

\section{Upaya Untuk Mengatasi Hambatan Pada Supervisi \\ Akademik Di SMA Negeri 1 Bengkulu, SMA Negeri 2 Bengkulu Dan SMA Negeri 4 Bengkulu.}

Dari data yang didapatkan upaya untuk mengatasi kendala pada supervisi akademik dan pembelajaran sosiologi berikut ini.

a. Solusi untuk mengatasi hambatan pada pelaksanaan supervsi akademik yaitu kepala sekolah akan memberikan waktu luang bagi guru-guru untuk diskusi mengenai kelemahan mereka dalam mengajar, yang kedua yaitu guru sosiologi harus mengikuti MGMP Sosiologi untuk memecahkan permasalahan yang dihadapi mereka. Serta komunikasi antar teman sejawat (R1, R3, R5, Wawancara).

b. Untuk mengatasi kendala pada supervisi akademik yaitu pihak sekolah akan bekerjasama dengan pengawas dari diknas atau bekerjasama dengan wakil kurikulum. Selanjutnya supervisi harus dilaksanakan berkala yang kedua memberikan pemahaman bagi guru bahwa supervisi itu sangat penting untuk

memperbaiki kinerjanya (R1, R3, R5, Wawancara).

c. Selain upaya yang ada diatas, upaya lainnya yang dilakukan pihak sekolah untuk mengatasi kendala pada supervisi akademik yaitu memberikan pelatihanpelatihan kepada guru/ mengupayakan pendekatan kelompok kerja sosiologi (R1, R3, R5, Wawancara).

\section{Pembahasan Dan Analisis Hasil Penelitian}

Supervisi

akademik bertujuan untuk membantu guru memperbaiki kegiatan pembelajarannya. Namun masih banyak guru sosiologi dari 3 SMA Negeri yang masih memiliki kendala dalam pembelajaran sosiologi yaitu salah satunya masih kurangnya jam wajib mengajar guru sosiologi yaitu 24 jam, ini dikarenakan guru di setiap SMA Negeri 1, SMA Negeri 2 dan SMA Negeri 4 Bengkulu masih banyak sehingga tidak sebanding dengan jumlah kelas yang sedikit. Ini salah satu yang menyebabkan kinerja guru menjadi menurun, karena beban tugas yang diberikan menjadi lebih sedikit. Sebagaimana kita tahu, bahwa dengan guru mengajar 24 jam perminggu ini dapat meningkatkan kinerjanya karena adanya beban mengajar tersebut sehingga guru tersebut memiliki tanggung jawab yang lebih terhadap kinerjanya.

Begitu juga untuk supervisi yang dilakukan oleh pengawas dari 
Diknas yang dilakukan hanya 2 kali dalam 1 tahun ajaran, ini masih sangat kurang efektif sehingga supervisi lebih banyak dilakukan oleh kepala sekolah dengan bantuan guru sejawat, disini pun kepala sekolah memiliki keterbatasan waktu untuk melaksanakan supervisi, hal ini terjadi disebabkan kesibukan akan tugas kepala sekolah lainnya yang harus diselesaikan. Untuk itu untuk membantu guru sosiologi tersebut akan lebih efektif bila supervisi dilakukan 3 kali dalam satu semester sehingga kinerja guru sosiologi dapat terkontrol dengan baik. Dengan dilasanakan 3 kali supervisi akademik, ini dapat diharapkan kinerja guru sosiologi selain lebih terkontrol juga dapat meningkatkan lagi kinerjanya dalam pembelajaran.

Agar pelaksanaan pembelajaran sosiologi berjalan dengan baik, seorang guru harus memiliki perencanaan pembelajaran yang baik yaitu mulai dari perlengkapan mengajarnya sampai pada pengelolaan kelas yang harus baik. Namun masih banyak guru yang belum lengkap perangkat pembelajaran serta memiliki kendala dalam mengelolah kelas. Kemudian rata-rata hampir seluruh SMA Negeri yang ada di kota Bengkulu ini tidak memiliki guru sosiologi yang berlatar belakangkan Kependidikan, sehingga kebutuhan akan guru sosiologi di daerah ini sangat kurang. Kalaupun ada guru sosiologi yang memiliki latar belakang kependidikan, itu pun hanya ada 1 orang untuk seluruh SMA Negeri yang ada. Selain itu kinerja yang baik rata-rata hampir dipegang oleh guru senior, sedangkan untuk guru yang berada di bawah guru senior masih perlu disupervisi secara berkala.

Kendala pada pelaksanaan supervsi akademik, yaitu kurangnya dana, kalaupun ada dana itu hanya SMA Negeri 2 Bengkulu yang memiliki dana untuk pelaksanaan supervisi akademik diluar yang formal atau biasa dilakukan oleh pengawas Diknas. Padahal dengan adanya dana yang cukup, supervisi dapat dilakukan secara berkala dengan demikian kinerja guru akan semakin baik. Kendala lainnya yang menghambat peningkatan kinerja guru sosiologi yaitu kurangnya pelatihan atau penataran untuk guru-guru sosiologi, padahal selain diadakannya supervisi, untuk mengkontrol kinerja guru tersebut, diperlukan sejenis pelatihan diluar dari pada supervisi akademik tersebut. Tapi untuk mengatasi kendala tersebut, maka guru sosiologi diharuskan ikut MGMP Sosiologi, sehingga dengan adanya forum ini dapat menampung keluhan yang dialami guru sosiologi.

Walaupun penilaian dari hasil supervisi rata-rata kurang baik, tapi dengan berlatar belakangkan bukan kependidikan sosiologi, mereka mampu untuk mengajar sosiologi diluar bidang mereka, disini dapat ditarik kesimpulan bahwa supervisi akademik memiliki pengaruh bagi peningkatan kinerja guru sosiologi. Yang menjadi ukuran dari adanya pengaruh tersebut yaitu adanya 
usaha dari guru-guru tersebut untuk melengkapi persiapan mereka yang masih kurang, selain itu adanya usaha mereka untuk mengikuti MGMP sosiologi setiap bulannya. Dengan adanya perubahan kecil ini, pengaruh dari supervisi tersebut sangat berdampak pada peningkatan kinerja guru sosiologi.

\section{E. Temuan Penelitian}

Selain melakukan penelitian ini peneliti menemukan temuantemuan dilapangan dari hasil wawancara, observasi dan catatan dokumen. Temuan pokok ini antara lain.

a. Jam wajib mengajar guru sosiologi yang ada di 3 SMA yaitu SMA Negeri 1 Bengkulu, SMA Negeri 2 Bengkulu dan SMA Negeri 4 Bengkulu, belum terlaksana 24 jam, tetapi masih 18 jam.

b. Supervisi yang dilaksanakan di 3 SMA yang peneliti dapatkan, dalam 1 tahun ajaran hanya dilaksanakan 2 kali, yaitu pada semester awal dan semester akhir, supervisi ini yang biasa dilakukan oleh pengawas Diknas.

c. Ketidak tepatan waktu antara kepala sekolah dengan guru sosiologi yang akan disupervisi, ini dikarenakan kesibukan kepala sekolah terhadap tugas internal dan eksternalnya sehingga waktu untuk pelaksanaan supervisi menjadi sangat terbatas. d. Persiapan mengajar guru masih belum siap, seperti perangkat mengajar guru yang belum lengkap, metode pengajaran yang masih belum bervarian, pengelolaan kelas yang masih kurang, penggunaan bahasa daerah yang masih sangat kental, serta pengelolaan waktu pembelajaran yang tidak tepat.

e. Di seluruh SMA Negeri yang ada di kota bengkulu masih banyak guru sosiologi yang bukan lulusan kependidikan sosiologi, kalaupun ada hanya 1 orang guru yang memiliki latar belakang kependidikan sosiologi.

f. Pembelajaran di luar kelas yang masih sangat terbatas ini dikarenakan kurangnya dana untuk pelaksanaannya.

g. Penataran dan pelatihan untuk guru sosiologi masih sangat kurang, dari 3 SMA Negeri yang ditemukan, hanya 1 orang guru dari masing-masing SMA yang baru mengikuti pelatihan atau penataran.

h. Kurangnya guru senior atau guru sejawat yang membantu kepala sekolah dalam melaksanakan supervisi akademik.

\section{F. Kesimpulan}

1. Pelaksanaan supervisi akademik yang diperoleh di SMA Negeri Bengkulu, hanya dilaksanakan 2 kali dalam 1 
tahun ajaran yaitu pada semester 1 dan semester 2 oleh pengawas Diknas. Selain pengawas Diknas supervisi juga dilaksanakan oleh kepala sekolah yang bekerjasama dengan guru senior/sejawat yang dilakukan sesuai dengan kebutuhan guru Sosiologi tersebut. Pelaksanaan supervisi biasa dilaksanakan dengan cara diskusi.

2. Bahwa pelaksanaan supervisi akademik memiliki pengaruh terhadap peningkatan kinerja guru sosiologi. Hal ini dilihat adanya usaha guru untuk melengkapi kekurangan akan kelengkapan persiapan mengajar yaitu penyusunan program pengajaran, penyajian program pengajaran yang sudah sesuai dengan program pengajaran, untuk evaluasi dan analisis pembelajaran sudah cukup baik, ini dilihat dari ketersediaannya buku penilaian siswa untuk masing aspek yaitu kognitif dan afektif. Kemudian pengadaan pengayaan dan remedial yang sudah dilaksanakan, walaupun pengadaan ini sering dilaksanakan diluar jam pelajaran sekolah, hal ini terjadi dikarenakan kurangnya jam pelajaran sosiologi di SMA Negeri Bengkulu. Hasil supervisi akademik yang diperoleh guru sosiologi di SMA Negeri Bengkulu, sudah mencapai 80 sampai 90.

3. Adanya hambatan pada pelaksanaan supervisi akademik yaitu penentuan jadwal/waktu kepala sekolah dengan guru yang akan disupervisi sangat terbatas dan kurangnya dana dalam RAPBS untuk pelaksanaan supervisi akademik. Selain itu kurangnya guru senior/sejawat untuk membantu kepala sekolah melaksanakan supervisi akademik.

4. Upaya untuk mengatasi hambatan pada pelaksanaan supervisi yaitu kepala sekolah memberikan waktu luang bagi guru-guru untuk diskusi mengenai kelemahan mereka dalam mengajar, yang kedua pihak sekolah akan bekerjasama dengan pengawas dari diknas atau bekerjasama dengan wakil kurikulum. Upaya lainnya yaitu supervisi harus dilaksanakan berkala yang kedua memberikan pemahaman bagi guru bahwa supervisi itu sangat penting untuk memperbaiki kinerjanya, dan memberikan pelatihan-pelatihan kepada guru/ mengupayakan pendekatan kelompok kerja sosiologi.

\section{Daftar Pustaka}

Abdul Rachman Abror. 1993. Psikologi Pendidikan. Yogyakarta: Tiara Wacana Yogya.

Hadari Nawawi. 1991. Metode Penelitian Bidang Sosial. Yogyakarta: Gajah Mada University Press. Hamzah. B. Uno. 2006. Perencanaan Pembelajaran. Jakarta Bumi Aksara. 
| Supervisi Akademik Kinerja Guru

Sumadi Suryabrata. 1993. Psikologi Pendidikan. Jakarta: Rajawali.

Sutrisno. 2005. Revolusi Pendidikan di Indonesia. Yogyakarta: Ar-Ruzz.

Oemar Hamalik. (1992). Psikologi Belajar dan Mengajar . Bandung: Sinar Baru

Sardiman A.M. (2003). Interaksi dan Motivasi Belajar Mengajar. Jakarta: Raja Grafindo Persada.

Slameto. (1988). Evaluasi Pendidikan. Jakarta: Bumi Aksara.

Suharsimi Arikunto. (1980). Manajemen Pengajaran Secara Manusiawi . Jakarta: Rineka Cipta.

(1989). Manajemen Penelitian. Depdikbub Dirjen Dikti P2LPTK Jakarta.

— (1993). Prosedur Penelitian Suatu Pendekatan Praktik. Jakarta: Rineka Cipta. 
| Kristina Syahreza

DIMENSIA, Volume 4, No. 1, Maret 2010 | 60 